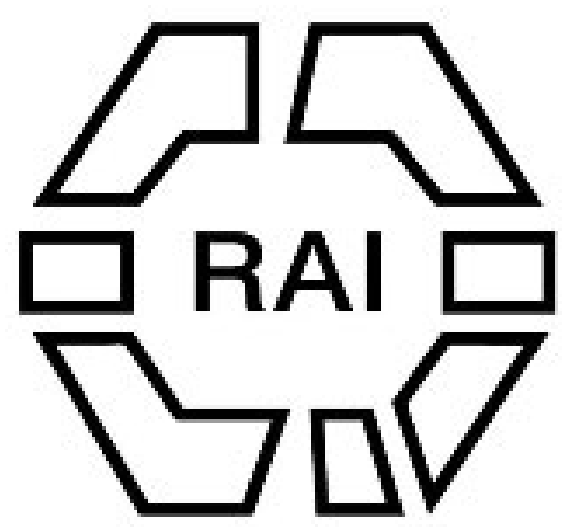

The "Paccha" of Ancient Peru.

Author(s): T. A. Joyce

Source: The Journal of the Royal Anthropological Institute of Great Britain and Ireland, Vol. 52 (Jan. - Jun., 1922), pp. 141-149

Published by: Royal Anthropological Institute of Great Britain and Ireland

Stable URL: http://www.jstor.org/stable/2843775

Accessed: 24/06/2014 21:07

Your use of the JSTOR archive indicates your acceptance of the Terms \& Conditions of Use, available at http://www.jstor.org/page/info/about/policies/terms.jsp

JSTOR is a not-for-profit service that helps scholars, researchers, and students discover, use, and build upon a wide range of content in a trusted digital archive. We use information technology and tools to increase productivity and facilitate new forms of scholarship. For more information about JSTOR, please contact support@jstor.org. 


\title{
THE "PACCHA" OF ANCIENT PERU.
}

\author{
By T. A. Joyce.
}

\section{[With Plates X-XIII.]}

IN the exhibition of Indigenous American Art, organized by the Burlington Fine Arts Club in 1920, were exhibited (Case L, Nos. 31 and 32) two remarkable wooden objects, ornamented with an inlay of mastic, which gave rise to considerable speculation as to their actual use. These had kindly been lent by the late Mr. James Guthrie Reid. In the autumn of the same year Mr. Louis Clarke sent me a note of a similar object in the Peabody Museum, Cambridge, Mass., of which, by the kindness of Mr. S. K. Lothrop, I was able later to obtain a photograph. The three are figured on $\mathrm{Pl}$. X. Some months after, while engaged upon certain researches relating to quite another subject, I was so fortunate as to discover, quite by accident, not only the particular function, but also the name, of these utensils. I will first describe the individual specimens, and then proceed to a discussion of their use. Pl. X, Figs. 1 and $1 \mathrm{~A}$ is carved from solid, hard, mahoganylike wood in the form of a plank, rectangular in section. At one end is the standing figure of a carnivore, supporting on its back a round bowl, the posterior margin of which has been broken at an early date and patched with a fragment of gourd, held in position by a resinous cement. In front of the animal's head is seated a human figure, with hands to mouth. A channel passes from the bowl through the heads of the animal and the man, so that any liquid poured in the bowl would issue from the man's mouth and fall between his outstretched legs. Thence it would flow through a deep double zigzag channel to the end of the utensil (which is imperfect, this end having evidently been cut off). The whole is ornamented with an inlay of coloured mastic - red, yellow, dark green, pale green, white, and black. On either side of the bowl is a butterfly (Fig. 1A) ; on the upper surface of the channelled portion are a catfish, a lizard, and conventional insects (Fig. 1c) ; while on each side are conventional designs, enclosed in squares, and staves with star-heads, alternating (Fig. 1B). The carnivore's eyes are indicated by mastic inlay, but those of the man consist of small pierced discs of turquoise. (Length, $20 \frac{1}{2}$ inches.)

The other specimen (Pl. X, Figs. 2 and 2A) is similar in pattern, though the bowl and supporters are lacking. The presence of a square hole at one end would seem to indicate that the bowl portion was, in this case, separate from the rest of the utensil, and affixed to it as occasion might demand. The liquid from the bowl 
would fall into a square reservoir, whence it would pass, again by a double zigzag channel, to the other end of the object, which is furnished with a pierced spout in the form of a jaguar's head. This specimen is also ornamented with an inlay

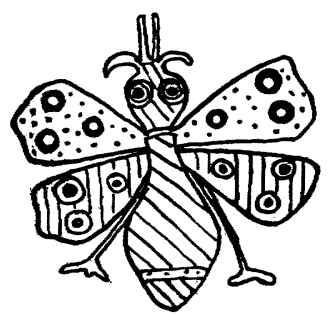

A.

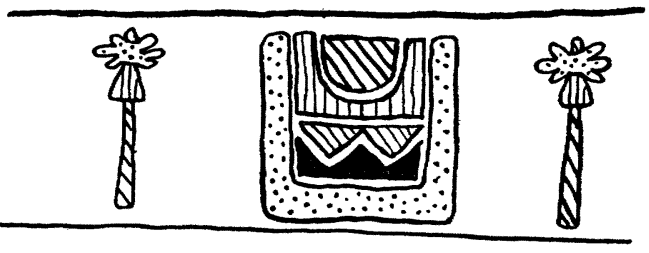

B.

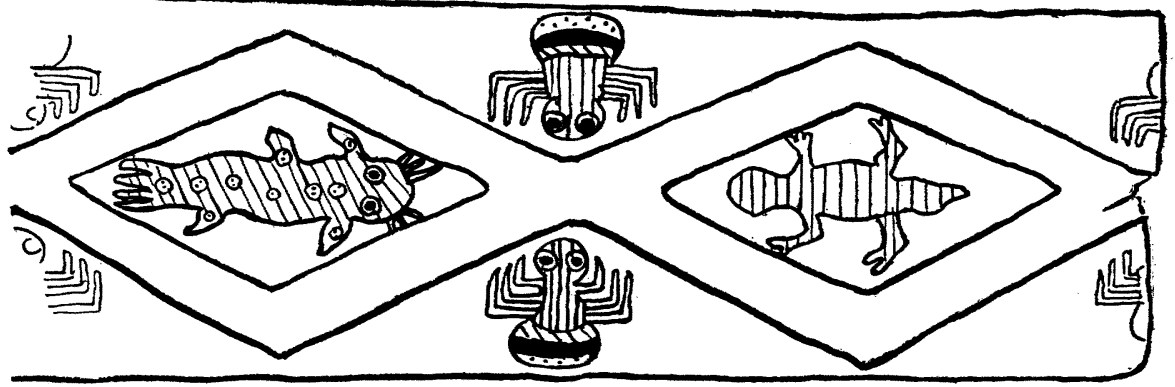

C.

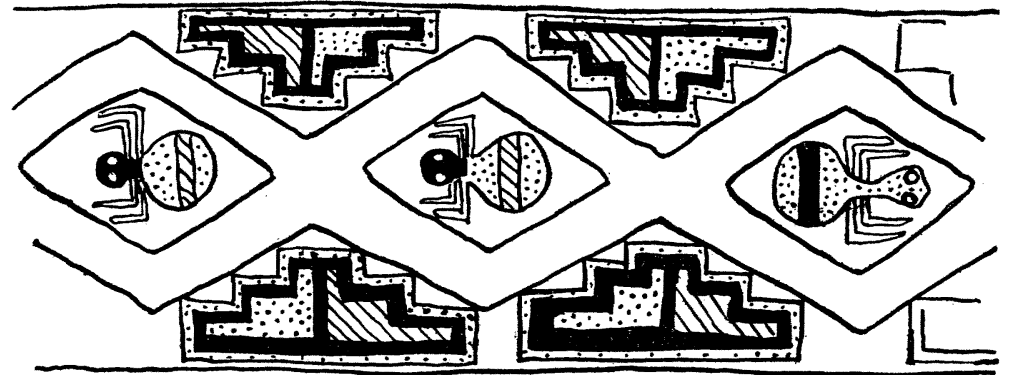

D.

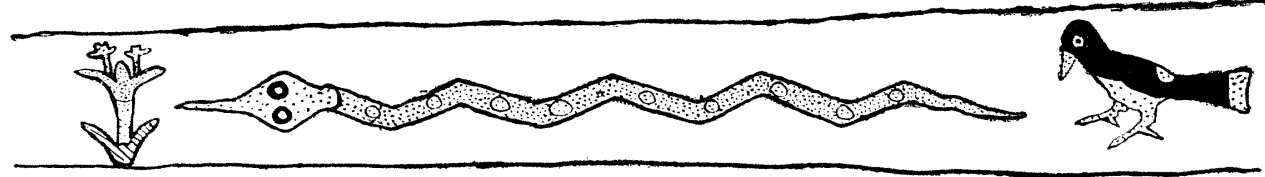

E.

FIG. 1.

of mastic in green, two yellows, white and black. On the upper surface of the channelled portion, along the edges, each angle of the zigzag contains a step-design, while each of the lozenge-shaped knobs shows an insect similar to those of the other specimen (Fig. 1D). On each side is a bird, two snakes, and a flower (Fig. 1E), 
and the jaguar's head is ornamented with black spots on a yellow ground. (Length, $25 \frac{1}{4}$ inches.)

Of similar type is the Peabody Museum specimen (Pl. X, Fig. 3), but this is perfect. In front of the bowl is a human torso, prone, with outstretched arms. The liquid in the bowl would fall from his mouth into a square reservoir, and, after passing through double zigzag channels, would finally issue from a plain conical spout at the extreme end. A short handle projects from the base of the bowl. Mr. Lothrop kindly sent me drawings of the mastic ornament, which is in two reds, green, yellow (?), white and black. The bowl has two scenes in panels, each once repeated. One shows a person seated on a stool and carrying a spear under a horseshoe-shaped "canopy," which terminates in puma heads (Fig. 2, 3). On either side of him stands a figure armed with a bow and quiver full of arrows. The other scene is a conventional tree, with a monkey and a bird on each side (Fig. 2, 1). The sides of the channelled portion show a flower and a humming-bird repeated alternately (Fig. 2, 2). (Length, 261 inches.)

During a visit to Madrid, my colleague, Mr. H. J. Braunholtz, found in the Museum yet another specimen of this utensil, and my friend, Mr. Louis C. G. Clarke, a week or two later wrote to me that he had discovered two examples there. By the kindness of Mr. S. K. Lothrop, who obtained me photographs, I am enabled to figure these (PI. XI, Figs. 1 and 2). Of them, Fig. 2 shows a similar "plank," supporting a bowl, and carved with a single zigzag channel with which the bowl communicates by means of a hole It is unornamented, and carries no indication of date. (Length, $21 \frac{1}{2}$ inches.)

Fig. 1, is extremely interesting; the bowl is in the form of a carnivore, and is studded with iron nails. The contents of the bowl do not issue from the animal's mouth, but pass by way of an aperture at the bottom of the bowl, through a straight concealed channel, which pierces the length of the "plank." At the same time, the double zigzag conduit, characteristic of the first specimens described, is indicated, in the form of an ornamental survival, in mastic inlay on the upper surface. Along the sides are series of figures, also in mastic inlay, wearing plumed hats and carrying firearms. Both the style of the ornament and the presence of the iron nails are

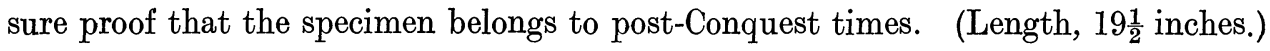

The explanation of the use of these peculiar utensils is to be found in Frézier's account of the voyage which he made in $1712-14 .^{1}$ In a description of an Indian feast which he witnessed at Talcahuano, he writes as follows :-

"Les femmes leur donnoient à boire de la Chicha, efpece de biere, dont nous parlerons ci-apres, avec un inftrument de bois long d'environ deus pieds $\frac{1}{2}$ compofé d'une taffe à manche d'une côté \& d'un long bec de l'autre, creufe d'un petit canal fait en ferpentant, afin que la liqueur coule doucement dans la bouche par un petit

1 Rélation du Voyage de la Mer du Sûd, par M. Frézier. Paris, 1732. 
trou percé au fond de la taffe à la tête de ce canal; avec cet inftrument ils s'enyvrent comme des Bêtes en chantant, fans interruption, \& tous enfemble."
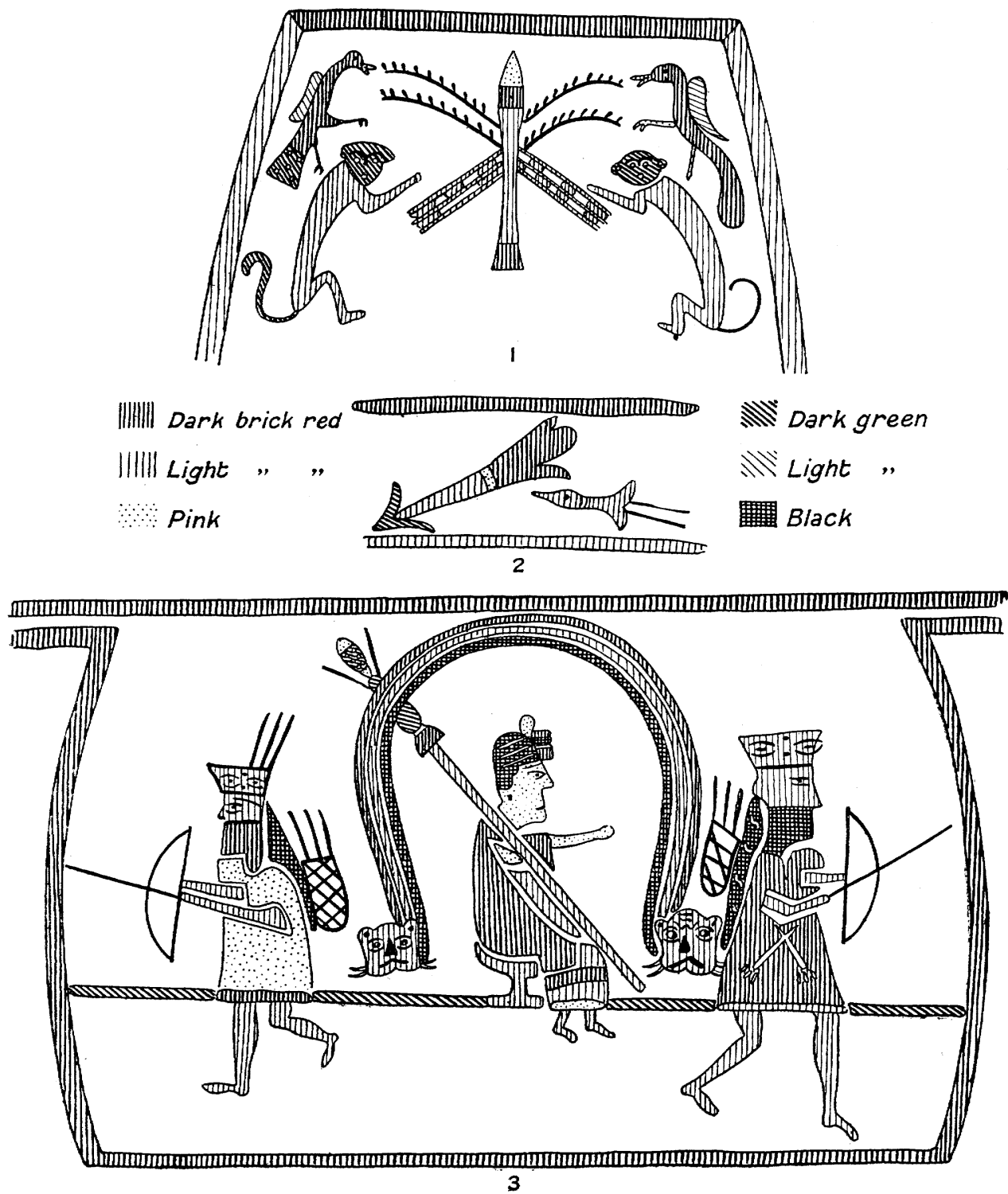

FIG. 2.

Frézier supplements his description by an illustration of the utensil, appearing at the foot of his Pl. IX, reproduced herewith (Pl. XII). From the letterpress accompanying the plate we derive the further information that it was called 
Paquech $a^{1}$, and, though the example figured exhibits a single zigzag channel instead of a double, I do not think that there can be any reasonable doubt that Frézier's Paccha and the specimens which I have described above are.one and the same thing. ${ }^{2}$

It may seem strange that the explanation of these peculiar objects, which are proved by their mastic ornamentation to belong definitely to the Inca culture, should have been reported from a region just outside the Inca sphere of control ; and it must be admitted that the details embodjed in Frézier's account show clearly that the feast which he describes was conducted on "Araucanian" lines. But two points should be remembered: first, that the Inca made more than one expedition south of the river Maule, and that, though they exercised no effective control south of the river, the small groups of settled agricultural communities had not remained uninfluenced by their culture; second, that Frézier's account is some 180 years later than the conquest of Peru, and that the transport, in numbers, of the more docile Peruvians as slaves, to assist in the exploitation of the country of the rather intractable Araucanians, cannot have failed to influence the local ethnography. The very word Paquecha I believe to be Kechua, the speech of the Inca people and the lingua franca of their empire. Tschudi, in his Kechua dictionary, gives a word paccha, with the following meaning: "(1) Subst. das Bächlein, die Quelle; arroyo, chorro de agua, fuente. (2) Verb, fliessen (vom Wasser), tropfen; correr el agua, gotear."

I think it is quite clear that the practice observed by Frézier in Chile was a survival of a Peruvian custom of the Inca period.

Next, with regard to the date of the particular specimens which constitute the subject of this note, I can only summarize briefly here. I hope to deal in detail with the whole question of inlaid mastic ornament at some future date. For the moment all I will say is that, from the evidence which I have been able to collect, this class of ornamentation did not come into vogue until quite late Inca times. That is to say, fourteenth century or so. It is quite certain that this particular form of technique survived the Spanish conquest. Mr. Louis Clarke possesses a wooden beaker from Copacabana with the figure of a man playing a harp (strangely enough of oriental pattern), ${ }^{3}$ while the British Museum collection includes another showing a man in cloak and hat sitting in a vessel with a sail. I am inclined to refer the Peabody Museum Paccha to the post-Spanish period from the fact that the human figure appears to be wearing a hat. As regards two other specimens

1 It must be remembered that Frézier was a Frenchman, writing in French, and that the spelling Paquecha, according to French phonetics, corresponds exactly to the word Paccha (with a "faucal gasp " between the $c$ 's) which is recorded in Middendorf's dictionary quoted below.

2 Frézier's illustration bears such a remarkable resemblance to the Madrid specimen figured on Pl. XI, 2 that one almost wonders whether they are not one and the same.

3 This form of harp was evidently common in Peru in post-Conquest times; see Wiener, Pérou et Bolivie, Paris, 1880, p. 187.

VOL. LII. 
figured on Pl. X, I will merely observe that the butterfly design relates the specimen on $\mathrm{Pl}$. X, Fig. 1 and 1A, with certain pottery discovered on the islands in Lake Titicaca, while the particular form of flower, illustrated in Fig. 1E (text) and the Peabody specimen, is characteristic of late Inca art. Of the Madrid specimens, Pl. XI, Fig. 1, is, to judge by the ornament, obviously post-Conquest; the date of the other, Pl. XI, Fig. 2, is uncertain.

To recapitulate, Frézier's experience related to Talcahuano- that is to say, a locality within the "Araucanian" region, and south of the river Maule, which formed the southern boundary of the Inca Empire: but we know that the Inca made many excursions south of the river, and that their cultural influence extended beyond the range of the effective political control exerted by them. At the same time we know also that long and extended drinking-bouts were a characteristic of the Araucanianspeaking nomads. The Paccha which I have figured belong to the late Inca period-that is to say, to the period after the Inca had come into close contact with the Araucanians, and that fact might very well give rise to the question whether it were not more reasonable to suppose that the Paccha was originally an Araucanian utensil, the use of which had been adopted by the Inca.

With.regard to this point, I have shown above that the name of the utensil almost certainly comes from the Kechua language. Secondly, we know that, at certain of the religious festivals in Peru, ${ }^{1}$ enormous quantities of chicha were consumed. Moreover, I think that there is evidence to show that this method of serving drink was very widespread in Peru in Inca times.

On Pl. XI, Fig. 4, is shown a pottery vase, moulded in the black ware, characteristic of the Truxillo region, which was manufactured there before the Inca conquest of the coast, but which prevailed until the coming of the Spaniards (and even later). It represents a bowl supported upon the pod of some leguminous plant, at the end of which is a small hole. It is in fact a Paccha translated into clay, the "plank" portion being moulded in vegetable form. (Madrid. Length, 16 $\frac{1}{2}$ inches.)

Pl. XI, Fig. 3, is even more interesting. Here we have a bowl in the form of a llama's head, supported upon a tapering "plank," the whole moulded from clay and ornamented with red and black slip. The ornament supplies the principal feature of interest, since the upper surface of the "plank" bears a design which can only be interpreted as a degenerate survival of the double zigzag channel which is the predominant feature of the specimens figured on $\mathrm{Pl}$. X. We have, thus, a complete series: the wooden "plank," grooved with its double zigzag channel; the wooden plank pierced by a straight conduit, but preserving in the ornament of its upper surface the original double meander; and the pottery form, in which the ornament.of the upper surface has so degenerated that, without the explanation

1 Such as Intip-Raymi. See my South American Archooology. London, 1912 ; pp. 165 and 166. 
provided by the other specimens, the pattern might well be regarded as merely

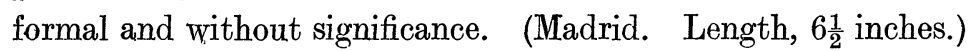

Pl. XIII, Fig. 1, illustrates a specimen similar to the last, but in the black ware of the Chimu period (like Pl. XI, Fig. 4). This is not furnished with any slip decoration, and consequently the last exterior indication of the channel has disappeared, though the form is still maintained. (British Museum. Length, $8 \frac{7}{8}$ inches.)

In Pl. XIII, Fig. 2, a departure from the typical form becomes evident. This vase apparently representts a man clinging to a balsa (reed raft); but there are still two apertures. Any liquid poured in at the "mouth" of the vase, situated between the man's feet, would naturally issue from the small hole at the pointed end of the conventional balsa. This vase is moulded in the same black ware of the Chimu period as the specimen immediately preceding. (British Museum. Length, $11 \frac{1}{4}$ inches.)

Having regard to the fertile imagination of the coastal population of northern Peru in design, it might naturally be expected that, once a departure had been made from the original form of the Paccha, a great variety of patterns might be produced; and I would suggest that many pottery vases, furnished with two apertures, may have served the same purpose.

Pl. XIII, Fig. 3, shows a vase of very remarkable pattern. Moulded from a reddish clay, and ornamented with geometrical patterns, it belongs to that class of object known as a "skeuomorph." Morphologically it may be divided into three elements : (1) a vase of the "aryballus" type, a type which is a constant element of Inca culture, supported on (2) an indeterminate hooked object, which is lashed to (3) a conical stem, which, to judge from the maize-cob projecting from its upper end (and incidentally forming an additional support to the " aryballus"), probably represents a maize-stalk. At the lower end of this stalk is a hole, through which any liquid poured in via the mouth of the "aryballus," would eventually issue. At the same time, if the "aryballus" is carried by the neck, and the thumb inserted in its mouth, the flow is stopped until the thumb is withdrawn. The axis of the "stalk," which runs diagonally to the vertical axis of the "aryballus," gives the right direction to the liquid if it is to be served to another person seated at a lower level. I would suggest that this is another form of Paccha. Unfortunately there is no information regarding this vessel, which is in the British Museum, to show from which part of Peru it came. The potting is that of the highlands, but the fantastic form belongs to the Truxillo area of the coast. It was probably made in the highlands by one of the coastal mitimaes deported thither after the conquest of the coast by the Inca at the end of the fourteenth century. (Length, 16 $\frac{1}{4}$ inches.)

Pl. XI, Fig. 6, shows a vase which is similar in essentials. Equally a skeuomorph, it represents an Inca "aryballus" resting in the mouth of another vase which, from the horizontal loop-handle, may be regarded also as a typical Inca form. At the base of the vessel is a spout, in the form of an animal's head, 
from which would flow any liquid poured in through the mouth of the upper portion, unless closed by a stopper or by the thumb of the person carrying it. This vase, however, is moulded in the typical black ware of the Chimu period and was, therefore, almost certainly made in the Truxillo region after the conquest of the coast by the Inca. (Bricish Museum. Length, 10 inches.)

In both these examples, the close connection with Inca culture is shown by the form of the vessel, but Pl. XI, Fig. 5, illustrates a pot of which the shape is characteristic of the northern coast. It is moulded from grey-buff clay, painted in brown slip, and represents a spiral shell. Though furnished with a lateral "flaring" mouth, it is provided, at the end of the spiral, with a small aperture through which the contents would flow in a manner recalling the other two specimens. The vase is undocumented, but the class of ware is late, and persisted into Inca times, especially in the region of Chancay. (British Museum. Length, $8 \frac{7}{8}$ inches.) If, then, vases of this type served the same purpose as the wooden Paccha described above, there is every reason to attribute them to late Inca influence.

In this connection I would make, though very tentatively, another suggestion. The following quotation is taken from my South American Archooology, p. 146 :-

"In many parts of Peru, especially in the neighbourhood of Cuzco, occur out-cropping rocks which have been carved with stairways, seats, and all manner of intricate channels leading from small reservoirs. Usually some sort of grotto or deep niche has been cut in the lower portion of these rocks, and human remains have been found in them. Uhle has suggested that these were the burial-places of important individuals, and that these small basins or reservoirs were intended for the reception of libations, which were supposed to reach the dead by means of the channels leading from them. . . . The same authority also suggests that the seat-like carvings, almost invariably called 'Seats of the Inca' . . . . were also connected with a festival to the Sun, at which the mummies were brought out from their sepulchres and shared passively in the ceremonies."

The suggestion which I make now is that the meandering and zigzag channels in the rocks, mentioned above, are really permanent Paccha consecrated to the use of the dead who were deposited in the neighbourhood. ${ }^{\mathbf{1}}$ The sculptured rocks in the environs of Cuzco are uncertain in date, but I think the assumption that they are of early Inca, or even pre-Inca, period is not unreasonable.

There can be no doubt that the utensils which I have illustrated on Pls. X and XI are identical with the Paccha observed by Frézier in Chile in the second decade of the eighteenth century. There is no doubt that they belong to the late Inca period, i.e. fifteenth century at latest. If I am correct in the suggestion that the pottery vases, figured on Pls. XI and XIII, performed a similar function, then it is clear that the use of some such utensil was so common in the Inca region

${ }^{1}$ In this connection I would refer to the Madrid specimen which, according to the label, was used for serving Chicha to the dead. 

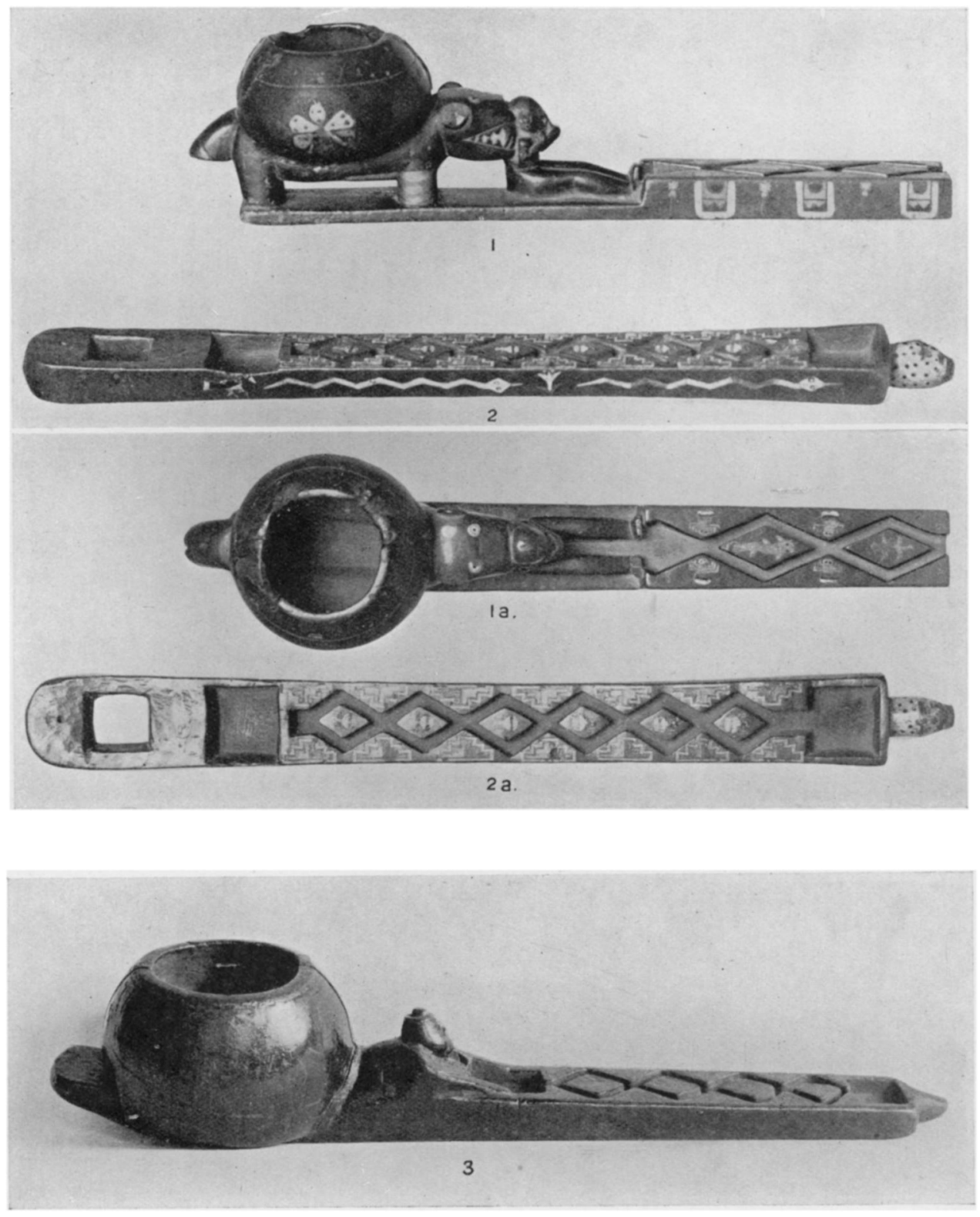

FIGS. 1, 1A, 2, 2A.-WOODEN "PACCHA."

FIG. 3.-WOOden " PaCcha," PEABOdy MUSEUM.

THE " PACCHA" OF ANCIENT PERU. 
Journal of the Royal Anthropological Institute, Vol. LII, 1922, Plate XI.

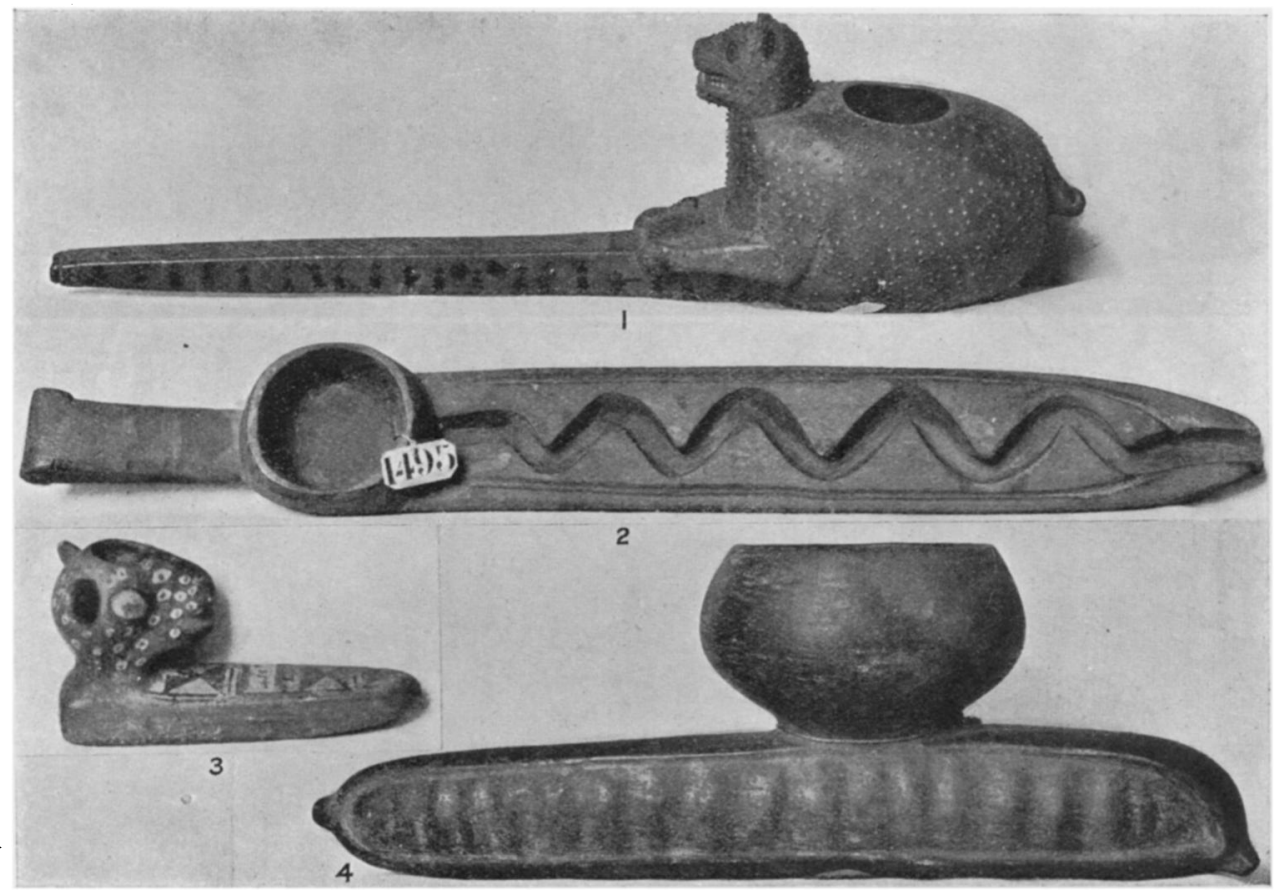

FTGS. 1 AND 2.-WOODEN " PACCHA," MADRID MUSEUM.

FIG. 3.-POTTERY "PACCHA," COAST AREA, MADRID MUSEUM.

FIG. 4.-POTTERY " PACCHA," CHIMU PERIOD, MADRID MUSEUM.

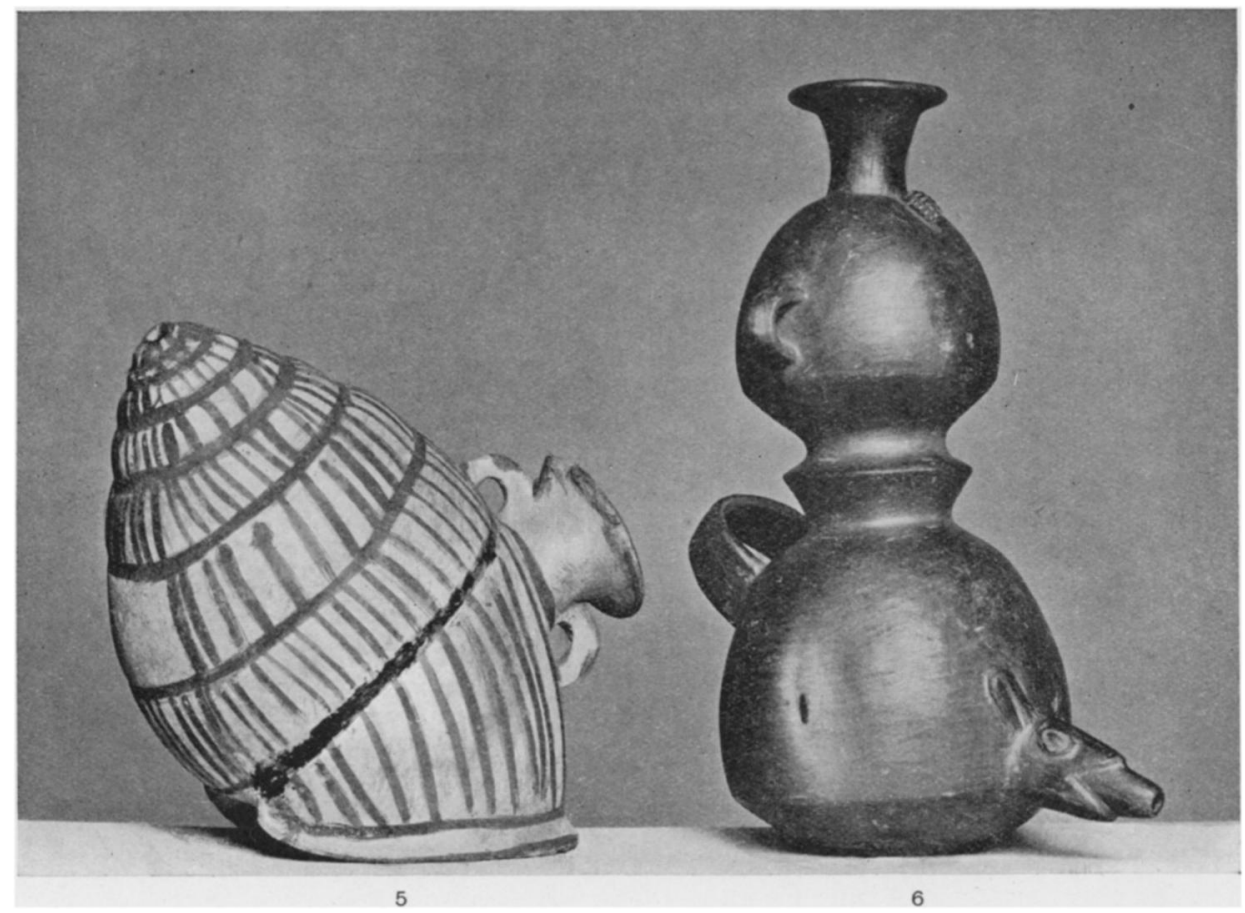

FIG. 5.-POTTERY (?) "PACCHA," COAST AREA, BRITISH MUSEUM.

FIG. 6. - POTTERY (?) “ PACCHA," POST-INCA CHIMU PERIOD, BRITISH MUSEUM.

THE " PACCHA" OF ANCIENT PERU. 


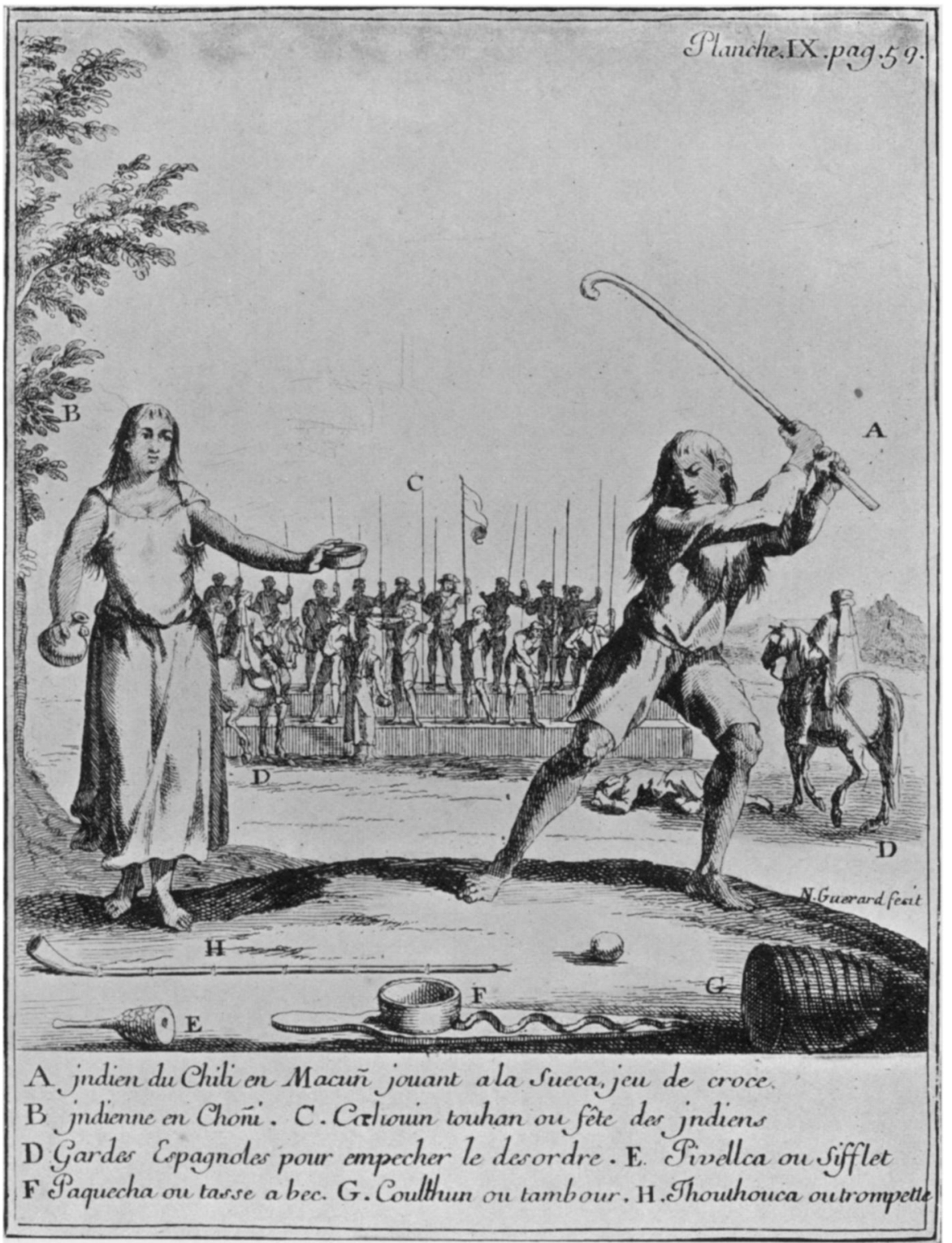

THE " PACCHA" OF ANCIENT PERU. 
Journal of the Royal Anthropological Institute, Vol. LII, 1922, Plate XIII.

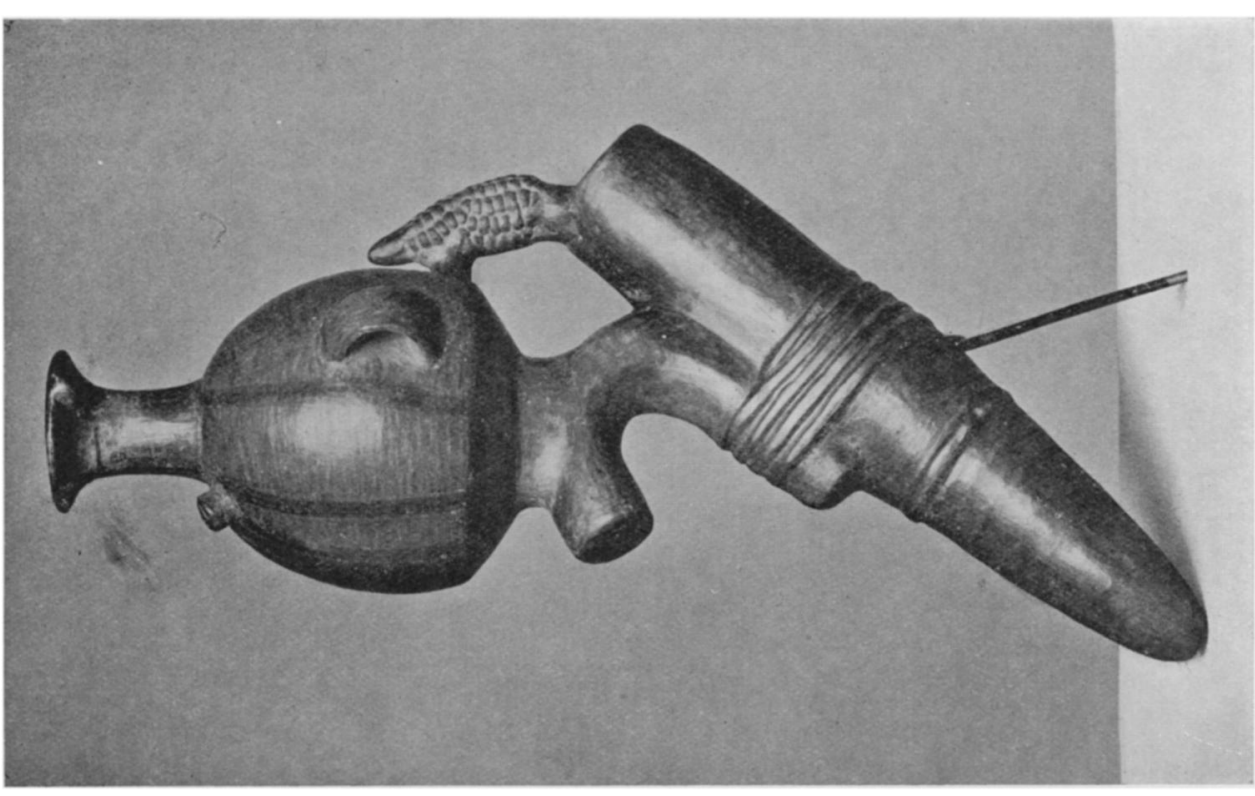

要
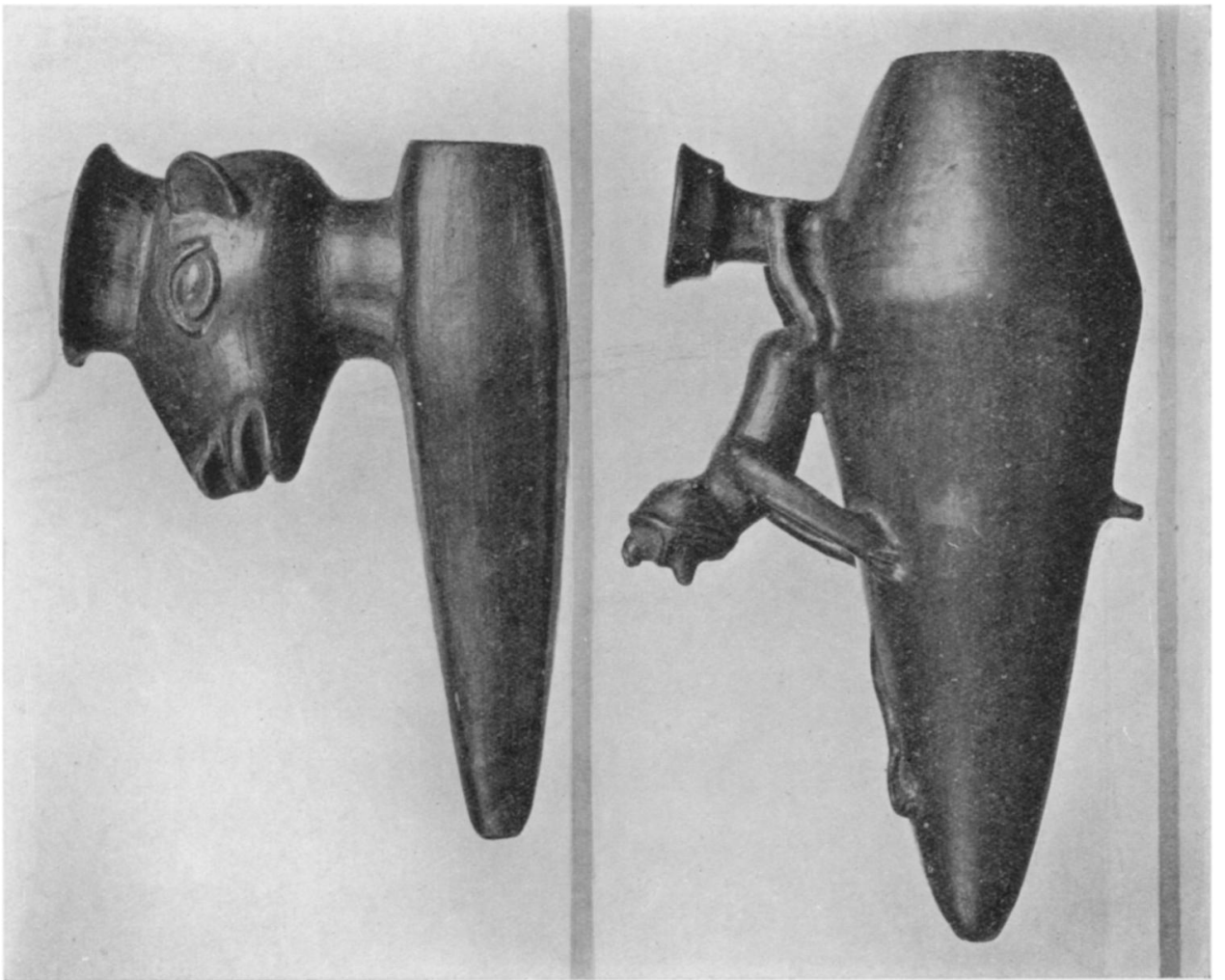

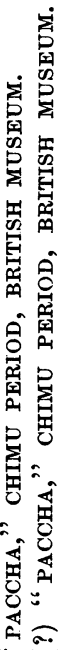

슬

管

要

i 요

i. i

压灾

N

THE "PACCha" OF ANCIENT PERU. 
at the time of the conquest of the coast (circa 1400) that it was transferred to the latter area as a natural consequence of the Inca conquest. At the same time, if I am right in the guess that the zigzag. channels in the outcropping rocks near Cuzco are related to the practice of ceremonial libations, then the principle of the Paccha belongs to a date considerably earlier, and is closely connected with the culture of the Peruvian highlands.

I have wandered, I admit, into the region of conjecture. The object of this note is the explanation of the use of a utensil so rare in collections that, when, in response to an appeal from the Burlington Fine Arts Club, two specimens were contributed to its exhibition of indigenous American art, their meaning baffled all the experts. That meaning, I think, finds its explanation in the passage and illustration reproduced above from Frézier. 